B)

Brazil and Africa 


\title{
Brazil and Africa
}

\author{
José Honório Rodrigues
}

Translated by

Richard A. Mazzara and Sam Hileman

$B \rightarrow$

UNIVERSITY OF CALIFORNIA PRESS

Berkeley and Los Angeles $\quad 1965$ 
University of California Press

Berkeley and Los Angeles

California

Cambridge University Press

London, England

(C) 1965 by The Regents of the University of California

Translated from Brasil e Africa: outro horizonte

(Rio de Janeiro: Editôra Civilização Brasileira, S. A.

I 961 ; Second Edition, revised and augmented, 1964)

Published with the assistance of a grant

from The Rockefeller Foundation

Library of Congress Catalog Card Number: 65-23155

Designed by Jorn B. Jorgensen

Printed in the United States of America

To Lêda, as ever

$\beta \rightarrow$ 
